\title{
Sustainability and CSR orientation through "Edutainment" in tourism
}

\author{
Mara Del Baldo
}

\begin{abstract}
The aim of the paper is to present and discuss, using a fieldwork approach, the pillars and the outcomes of sustainable business models in the tourism sector. After having traced the theoretical framework, which combines the literature strands of sustainable tourism and sustainable business model, the work is centered on the analysis of an exemplary case-study. On the basis of an action-research approach, it focuses on the experience of Costa Edutainment Spa, Italian leader in the management of public and private structures dedicated to recreational, cultural and educational activities. Findings show that that the CSR and sustainability orientation which affects the business model lies on both the culture and the identity of the company which is characterized since its foundation by a deep socio-economic involvement. Promoted by the entrepreneurial family. Moreover, the set of key values (responsibility towards people, the environment and the society) and external factors affecting the cultural and touristic sector the company belongs to, favour the development of educational projects addressed to stakeholders (customers, suppliers, scientific community, research centres) aimed at building up innovative paths of sustainability.
\end{abstract}

Keywords: CSR, Sustainable business model, Strong sustainability, Education, Entertainment, Tourism

\section{Introduction}

The conceptual construct used in this study considers a business model as "the rationale of how an organisation creates, delivers and captures value" (Osterwalder et al., 2005:14) or, in other words, as "the organisation's core logic for creating value" (Linder \& Cantrell, 2000). Value is intended as sustainable value, thus expressed in terms of economic, social, ethical and environmental performances.

Starting from these premises the paper aims to analyse and discuss the fundamentals (internal and external factors) which characterize the sustainable business model in the tourism sector.

The methodology here adopted is based both on a deductive and inductive research approach. The first one is founded on a brief literature review aimed to trace the theoretical framework, while the second one is empirically constructed and follows the "action research approach" (Benbasat et al. 1987; Sankaran et al., 2003) since it involves the analysis of the main Italian operator

Correspondence: mara.delbaldo@uniurb.it

Economics of Sustainability and Accountability; Financial Accounting, Department of Economics, Society, and Politics, School of Economics, University of Urbino Carlo Bo, Via Saffi, 42, 61029 Urbino, PU, Italy in "edutainment" (education and entertainment), namely Costa Edutainment Spa which represents an exemplary case study (Yin, 2003; Eisenhardt and Graebner 2007; Patton 2002). Costa Edutainment is in fact the Italian leader in the management of public and private structures dedicated to recreational, cultural, educational activities, as well as study and scientific research which manages 12 main structures at national and international level (such us theme parks and aquariums) and is characterized by a strong local involvement and a positive economic and environmental impact. The analysis has been developed across a multi-year period, beginning in 2014 and continuing today. It was based on information acquired through in-depth semi-structured interviews (addressed to the Costa Edutainment CSR Officer, the entrepreneur, external consultants, stakeholders), direct observation during round tables, multi-stakeholders forums and workshops. Moreover, the analysis of documentary sources (annual and integrated reports) has been carried out.

Findings show that that the sustainability orientation which affects the business model is strongly dependent on both the culture and identity of the company founded by a family whose key values (responsibility 
towards people, the environment and society), combined with external factors affecting the cultural and touristic sector to which the company belongs, favoured educational projects addressed to stakeholders (customers, suppliers, scientific community and research centres) aimed at building up innovative paths of sustainability.

The paper is divided into two main parts. First, the literature review is followed by the description of methodological approach. The second part introduces and discusses the case study. A final section sums up the main insights and conclusive remarks.

\section{Theoretical framework}

\section{The emergence of sustainable business models}

Since 1957, when the term "business model" appeared for the first time in an academic paper (Bellman et al. 1957), numerous definitions have been provided by the managerial literature (Zott and Amit 2007, 2008, 2009; Zott et al. 2011; Sorrentino and Smarra 2015).

According to Bocken et al. (Bocken et al. 2014) business model is defined by three main elements: the value proposition, value creation, delivery and value capture. While the value proposition is typically concerned with the product and service offering to generate economic return, in a sustainable business, the value proposition would provide measurable ecological and/or social value in concert with economic value. Accordingly, a sustainable business model (SBM) is a model where sustainability concepts encompasse a wide range of change within the organization and its external network, shaping the strategic orientation of the firm and its decision making (Abdelkafi and Täusher 2015), such as developing company culture toward sustainability, framing company values and translating them into principles and business practices, implementing sustainable strategy acquiring appropriate skills and knowledge across the value chain (through external resources and internal training, involving customer to better understand their needs and expectations of a sustainable company (Boons and Lüdeke-Freund 2013; Novak 2014; Schaltegger and Wagner 2011). Several SBMs archetypes have been categorized to develop a common language useful to accelerate the development of SBMs in research and practice. Among these, we can mention the following: maximize material and energy efficiency; create value from 'waste'; substitute polluting processes with renewable and natural processes; adopt a stewardship role in managing the business; repurpose the business for society and environment; and develop scale-up solutions and sustainable innovations (Schaltegger et al. 2012; Bocken et al. 2014; Almers 2013).

The need for developing SBMs and their implementation in practice has been pointed out by several authors (Visser 2011; Dean and McMullen 2007; Hall et al.
2010) who consider them fundamental for trigger more outward-oriented conceptions of CSR (corporate social responsibility) and sustainability (Schaltegger et al. 2016; Looser and Wehrmeyer 2015; Del Baldo 2012; Del Baldo and Baldarelli 2017) fashioned through dynamic and continuous interactions between individuals and groups inside and outside companies (Thompson et al. 2015). The elements that contribute to driving a transformation toward SMBs requires the building of networks and collaborative practices for learning and action around a new shared vision and generate social value creation (Seelos and Mair 2005, 2006; Johnson 2010; Patzelt and Shepherd 2011).

Although comparable conceptual notions of SBMs do not exist today (Lüdeke-Freund 2009; Schaltegger et al. 2016) the research agenda on SBMs provided by Boons and Lüdeke-Freund (2013) points out that the empirical research helps to shed some light on the state-of-the-art of corporate sustainability management, sustainable organizational development and sustainable innovation in daily business (Tukker et al. 2008). Empirical research is particularly useful to inquire the extent to which business model allow or hamper specific types of innovations (Johnson 2010) and to demonstrate how to translate social and environmental value creation into competitive advantage to build the 'business case for sustainability' (Dyllick and Hockerts 2002; Salzmann et al. 2005; Schaltegger et al. 2012). In addition, the use of case-studies allows us to identify the internal (structural and cultural) capabilities organization and the forms of collaboration with key stakeholders which are necessary for an organization to achieve sustainability for the socioeconomic and environmental system they belong to (Stubbs and Cocklin 2008).

\section{Sustainable and responsible business models in tourism}

CSR an sustainability orientation are no longer a luxury for companies belonging to any economic sector, included the travel and tourism sector. Although sustainable tourism is still under-investigated in comparison with other industries (Coles et al. 2013; Tamajòn and Font Aulet 2013) the sustainability orientation appears even more important in this context. Indeed, tourism is a people-centred industry, based on interaction with human resources, cultural and environmental assets and the host community in the destination (Kalisch 2002). Moreover, the environment and cultural heritage represent critical asset for the tourism product (Brent Ritchie and Crouch 2003). The core elements that contribute to the quality of tourism product and to customer satisfaction and loyalty (Martìnez and Rodrìguez del Bosque 2013) are closely linked to integrating environmental, eco-energy and water efficiency, eco-friendliness of the materials, as well as the quality of the environment, 
noise control, the quality of human resources, relationships, consistency of corporate values and open communication (Miller 2001; Tapper 2001; Budeanu 2009).

The World Conference held in Manila in 1980 and the Brundtland Report (UNWCED 1987) contributed to applying the concept of sustainability to tourism introduced by UN-World Tourism Organization (UN-WTO 1993). Sustainable tourism is a complex concept and a dynamic construct which includes many correlated concepts (Clifton and Benson 2006). It has been defined as the tourism that meets the need of the present tourists and host regions while protecting and enhancing the opportunity for the future (Responsible Travel Handbook 2006). Sustainable tourism emphasizes the need to preserve the local community, in terms of traditions and socio-cultural identity, protect the environment, generate revenue and labor for the host destination and involve the local community in decision-making processes (Medina 2005) giving rise to forms of shared territorial governance (Del Baldo 2017a). Accordingly, numerous 'labels' are associated with sustainable tourism: acceptable, appropriate, consistent, conscious soft, durable, eco-friendly, green, ethical, equitable, integrated, light, soft, non-random, not harmful, responsible, socially leg, and humanitarian-tourism. These labels also include accessible tourism, which addresses specific categories of people and, among these, the elderly, the disabled, or minority categories and groups (Manente et al. 2014).

The International Coalition for Responsible Tourism associated responsible tourism with the concept of sustainability, qualifying responsible tourism as an application of sustainable development within the tourism sector (UNEP 2005). The Responsible Travel Handbook states that responsible tourism goes beyond fancy packaging and eco-certification, or simplistic internal hotel policies of washing sheets and towels, or accommodations located in natural jungle. Rather it has to do with an everyday lifestyle that promotes cultural and biological diversity, environmental and natural resources conservation, at home and while travelling (see: Responsible Travel Handbook 2006: 13). This definition has been further developed (Second International Conference on Responsible Tourism Destinations held in Kerala in 2008) through guidelines and recommendations for actions in different fields (education, training, campaigning and awareness raising, media, governance, partnerships and markets) in order to promote it. Responsible tourism takes a variety of forms of travels that minimize negative environmental, social and cultural impacts, generate greater economic benefits for local people and enhances the well being of host communities, involve local people in decisions, make positive contribution to the conservation and valorization of natural and cultural heritage, provide access for physically challenged people and enjoyable experiences for tourists through meaningful connections with local people and a greater understanding of local cultural and environmental issues, and engender respect between tourists and hosts (Cape Town Declaration 2002). Therefore responsible tourism can be considered a sort of umbrella, which includes all types of tourism afore mentioned, included the fair-trade tourism, solidarity tourism, community based tourism, rural tourism, agro-tourism, heritage tourism, reality tourism, pro-poor tourism and conscientious tourism. "Responsible tourism is a broad concept that includes different conscious and respectful ways of travelling, which bring people to take responsibility for their actions while sustainable tourism represents the natural reply that tourist operators give in order to fulfill the needs and wishes of responsible tourists" (Manente et al. 2014: 12).

Among the organizations that have proposed their own definition, the Italian Association for Responsible Tourism (AITR) identifies responsible tourism as tourism developed according to the principles of economic and social justice and respecting the environment and local culture, thus supporting the positive interaction between the tourism industry, the local community and travelers/tourists. The numerous forms related to responsible tourism include the ecotourism which may find interesting spaces in Italy, being a country rich in historical and anthropological components (Cater 1993). This implies that tourism companies should be based on a sustainable business model, adopting a long term vision, implementing a triple bottom line and a multistakeholder approach (Dodds and Joppe 2005). It also means that they should be environmentally responsible, equitable, providing employment for the host population and educating tourists about environmental and social concerns, as the following case-study testify.

Based on the above a sustainable business model in tourism requires organization to be ethically-imbued and experiment a shift from 'weak' to 'strong sustainability' which maintains 'natural capital' while developing 'manufactured capital' (Ayres et al. 1998). Weak sustainability is the idea within environmental economics, which states that human capital can substitute natural capital. Contrary to weak sustainability, strong sustainability assumes that human capital and natural capital are complementary, but not interchangeable. In other words, weak sustainability maintains that man-made, manufactured capital is of greater importance than natural capital and can easily substitute it (Solow 1974, 1986, 1993; Hartwick 1977, 1978, 1990), while strong sustainability recognizes that natural capital is often not substitutable by man-made capital and in certain instances can never be substituted by it. Unlike weak sustainability strong sustainability puts the emphasis on ecological scale over economic gains. This implies that 
nature has a right to exist and that it has been borrowed and should be passed on from one generation to the next in its original form. One thus can argue that strong sustainability is addressed to integral development (Schieffer et al., 2014; Jakobsen et al. 2017; Sorci 2007). The integral development involves all aspects of the enterprise and requires a business model derived from the strategy, while in weak sustainability the business model is decoupled or weakly related to the strategy.

"The practical expression of the strong sustainability concept is likely to be in terms of preservation of certain species (or genera), safe minimum standards for impacts on environmental quality and sustainable use of renewable natural resources" (Ayres et al. 1998: 8). By contrast, weak sustainability concerns the reduction of strategic and operational "unsustainability". Referring these concepts to the tourism businesses, weak sustainability aims at considering eco-efficiency when measuring and calculating the impact on the ecological environment (Bebbington 2007:26). A practical interpretation of this type of sustainability is, for example, when enterprises participate in projects such as EMAS (Eco Management Audit Scheme). Weak sustainability may also concern eco-justice, which consists in examining the intra and inter-generational distribution of resources, including social and environmental performance. By contrast strong sustainability implies that the tourism enterprise fully implements the dimensions of sustainability (economic, social, environmental and ethical dimensions) not only by measuring the results of the impact of its activity on the environment and the community, but also investing for the preservation and the flourishing of the same (Schieffer et al., 2014). This perspective can also be referred to the process and tools tourism companies adopt to both communicate and report their activities and engage with stakeholders. In this regard, under the weak accountability perspective an organization communicates non-financial information with the aim to a positive signal regarding its reputation (Simaens and Koster 2013). In the strong accountability perspective organizations accept social and environmental responsibility as an ethical obligation that lies at the core of the business model and integrate in their accountability system a responsibility towards an efficient, ethical and effective use of resources (Garriga and Melé 2004) such as the following case demonstrates.

\section{Methodology}

The empirical study has been developed using a qualitative approach and a case-study method (Yin 2003; Eisenhardt and Graebner 2007; Patton 2002). Costa Edutainment Spa has been selected for two main reasons. First, it represents the leading Italian edutainment operator and thus provides an exemplary case in the tourism sector. Second,
Costa Edutainment has been included among the Italian pivotal companies that, within the Italian Network for Business Reporting (an organization that, in turn, is part of the World Intellectual Capital Initiative and collaborates with the Integrated International Reporting Council - IIRC), started the implementation of the integrated reporting process. Costa Edutainment released its first integrated report in 2014, aimed at strengthening the stakeholder engagement, the connectivity among input and performance, and a structured communication of its sustainability orientation (Costa Edutainment 2014, 2015, 2016). Therefore, with regard to the first criterion, Costa represents a best practice in a specific tourism niche (management of aquariums, marine and thematic parks at national and international level, dedicated to recreational, cultural, educational activities, study and scientific research) whose activity is highly affecting by environmental and social aspects. Costa is in fact involved in educational and research activities addressed to the local, national and international community, putting a particular attention to the children, their families, as well as the scientific and research institutions active in environmental and animal preservation and protection. The case study is thus particularly relevant since it concern the Italian leader in the afore mentioned sub-sector. It is different from other residual entities in the same area since there are not other companies in the country, nor private or public-based, with a similar offer of edutainment products and services. There are only minor organizations, usually smaller in size and with a local or at least national offer. Moreover, Costa is a private entity and a family-based company, while similar activities in Italy (and often also in Europe) are usually managed by public organizations operating at a local or regional level, or as mixed (public-private) networks. With regards to the second criterion, Costa is the unique company belonging to the tourism sector that adhered to the Italian pivotal group of firms involved within the IIRC and NIBR group in implementing an integrated report aimed at disclosing in a transparent and consistent way its process of value creation centered on sustainability and responsible management.

The fieldwork approach facilitates the researchers' involvement in the company's activity with a view to studying the processes and the organizational practices of social, environmental accounting and accountability (Adams 2002; Dumay and Dai 2017). In this paper we adopted a descriptive case study approach (Ryan et al., 2002). Case studies are particularly suitable for research areas where there are a few prior theoretical pieces of literature or empirical research works (Eisenhardt, 1989) and the most appropriate research question are those asking "how" and "why" (Yin 2003) rather than those requiring broad statistical analysis. Having a widespread application for teaching purposes, case studies can also 
be seen as a guide to establishing a frame for data collection in a particular piece of research, thereby seeking to cover contextual conditions, which might be relevant for the phenomenon being studied (Herzig et al. 2012). Namely, an action research approach has been adopted, being the researcher part of the same group involved in releasing a guidance for the implementation of the integrated reporting process in small and medium-sized companies (Del Baldo 2017b).

The analysis was developed across a multi-year period (beginning in 2013 up to 2017, March) and based on information acquired through a triangulation of methods and related sources: two in-depth semi-structured interviews addressed to the Costa Edutainment CSR Officer, the entrepreneur and external consultants (a content analysis of the interviews was undertaken using qualitative coding techniques); informal conversations with the members belonging to the multi-stakeholder group within the Italian Network of Business reporting (formed by scholars, entrepreneurs, managers, IIRC representatives, consultants agencies, banks, business associations); direct observation during the round tables, forums, workshops, and on the analysis of internal and external documentary sources (company reports and integrated reports) and web sustainability information posted on the company internet site.

\section{Case-study: a sustainable tourism perspective through education and entertainment}

Costa Edutainment Spa is the Italian leader in managing public and private structures (12 parks and facilities at national and international level, including Genoa Aquarium, the largest aquarium in Europe, and the Mediterranean Marine Park in Malta) dedicated to recreational, cultural, educational activities, study and scientific research. By 31st October 2014 it had 106 employees and a turnover of over 25 million euro. In 2015, after the partnership with the investment funds VEI Capital and the merge with Costa Parchi (Costa Parks) the company reached an annual turnover of around 52 million euro, almost 500 employees and 2.6 million visitors. In 2016 it had 508 employees, a turnover of 53 million euro and 3 million visitors. The most relevant highlights relative to 2016 are summarized as follow (Table 1).

Recently, Costa Edutainment has been included in Civita Group, that is part of the new Italian Entertainment Network (IEN), a leading tourism operator specialized in managing services and events for cultural activities (i.e., the management of the commercial activities of the Vatican Museums or the Uffizi Gallery in Florence). Costa Edutainment is also part of several companies and foundations belonging to the same group (such as Costa 14, the Foundation Acquario di Genova Onlus, Bioparco of Rome and the Ducal Palace of
Table 1 Costa Edutainment highlights (2016)

\begin{tabular}{|c|c|}
\hline Visitors & $\begin{array}{l}3,000,000 \text { (of which } 156,000 \text { students) } \\
(+15 \% \text { calculated by reference to the } \\
\text { previous year ( } 2015 \text { ). }\end{array}$ \\
\hline Turnover & 57 million euro \\
\hline EBITDA & 9.5 million euro $(+80 \%)$ \\
\hline Net Financial Position & - 35 million euro \\
\hline Distributed Added Value: & 38 million euro \\
\hline Customer satisfaction & 8.64 \\
\hline \multirow[t]{3}{*}{ Consumption } & 291,000 Cubic meters of water $(-10 \%)$ \\
\hline & $25,600,000$ energy KWH (- 5\%) \\
\hline & 893.000 Cubic meters of gas $(-16 \%)$ \\
\hline Emissions & 13,8kt CO2 emission \\
\hline Website & $2,200,000$ website visitors \\
\hline Social Networks & 382,000 social networks "likes" \\
\hline
\end{tabular}

Genoa) and manages at the national and international level a plurality of public and private partnerships (Table 2), thus being a key actor of a multitude of tourism and cultural events (i.e., the Festival of Science, the Festival of Communication in Camogli and the Festival of the Mind).

Table 2 Costa's Public and private Partners

\begin{tabular}{|c|c|}
\hline Foundations & $\begin{array}{l}\text { Palazzo Ducale Fondazione per la Cultura di } \\
\text { Genova }\end{array}$ \\
\hline \multirow[t]{2}{*}{ Theaters } & Teatro Stabile di Genova \\
\hline & Teatro Carlo Felice di Genova \\
\hline \multirow[t]{4}{*}{$\begin{array}{l}\text { Public and Institutional } \\
\text { Partners }\end{array}$} & $\begin{array}{l}\text { Regione Emilia Romagna, Liguria e Toscana } \\
\text { (with the Municipalities of: Genova, Livorno, } \\
\text { Rimini, Riccione e Cattolica) }\end{array}$ \\
\hline & Chamber of Commerce in Genova \\
\hline & $\begin{array}{l}\text { Entrepreneurial Associations } \\
\text { (Confindustria Genova, Confindustria Rimini, } \\
\text { Confcommercio) }\end{array}$ \\
\hline & $\begin{array}{l}\text { Tourism Consorthia (in Rimini and Riccione, } \\
\text { Italy). }\end{array}$ \\
\hline \multirow[t]{4}{*}{ National Associations } & $\begin{array}{l}\text { Associazione Promotori Musei del Mare } \\
\text { (Association of Promoters Museums of } \\
\text { the Sea) }\end{array}$ \\
\hline & $\begin{array}{l}\text { UIZA - Unione Italiana Giardini Zoologici e } \\
\text { Acquari (Italian Union of Zoological Gardens } \\
\text { and Aquariums) }\end{array}$ \\
\hline & $\begin{array}{l}\text { Confcultura - Associazione Imprese Museali } \\
\text { (Association of Museum Companies) }\end{array}$ \\
\hline & $\begin{array}{l}\text { NIBR - Network Italiano Business Reporting } \\
\text { (Italian Network on Business Reporting) }\end{array}$ \\
\hline \multirow[t]{3}{*}{$\begin{array}{l}\text { European and } \\
\text { International Associations }\end{array}$} & $\begin{array}{l}\text { EAZA - European Association of Zoos and } \\
\text { Acquaria }\end{array}$ \\
\hline & OIE - World Organization for Animal Health \\
\hline & $\begin{array}{l}\text { IIRC - International Integrated Reporting } \\
\text { Council }\end{array}$ \\
\hline
\end{tabular}


"The corporate partnership and the merge with VEI Capital partner at the end of 2015, has proved to be a key strategic choice which increased experience, resources and energies, and enhanced the overall quality and the innovation of our way of doing business, while preserving the ties with our history and our values, never secondary to our economic goals" (Executive President of Costa Edutainment Spa, Costa Integrated Report, 2016, Presentation: 5).

The term Edutainment is a fusion of education and entertainment and sums up the company's mission: provide a reply to the growing demand in the qualitative use of free time by blending culture, education, events, emotion and fun into a meaningful experience. The entrepreneurial spirit, triggered by the founder and current President, B. Costa, as well as the strong educational mission and close ties to the territory, make Costa Edutainment a unique group in Italy able to guarantee strong local involvement and economic impact in the operative area.

Being part of a family group, Costa Edutainment is a family-based company lasting from several generations of the Costa's family. It was originally set up in Genua in 1849. The first activity was the trading of Italian olive oil in North and South America. The business history intersects the roots with the entrepreneurial family, whose system of values (respect for people, solidarity, honesty, dedication to work, creativity, respect for the tradition and the environment) has characterized over time a way to make a recognizable and long-lasting enterprise.

"The company's leadership finds its roots in the original entrepreneurial spirit linked to the name of the Costa family, which is born in the oil field and during the decades started to embark on cruise tourism, affirming itself as one of the most important and quality brands in Italy and worldwide and acquiring over the years a cross-sector know-how in different" (Costa Edutainment Integrated Report, 2016: 5).

Costa Edutainment's activity started with the foundation of the Genoa Aquarium - designed by the famous Italian architect Renzo Piano - which was set up on the occasion of the Expo in 1992 for the celebration of the fifth centenary of the discovery of the New World by Cristoforo Colombo. In 1997 some members of the family founded Costa Edutainment (originally named Costa Aquarium) and created Incoming Liguria (currently named CWay) a tour operator born from the collaboration and the know-how of two important brands in the sector: Costa Edutainment and Civita Culture. CWay offers trips that combine art, culture, nature, entertainment and fun, enabling visitors to experience edutainment, entertaining, education and fun, respecting both the traditions and values of over 100 destinations that represent the best offer of Italian cultural and tourism heritage. Coherently, the guiding principles of Costa Edutainment are: emotions, innovations and sustainability. These principles are implemented through the entrepreneurial actions which are focused on eight business model pillars (Table 3 ).

The entrepreneurial spirit, the strong educative mission and the embeddedness to the territory - those factors which are typically of many Italian companies (Del Baldo 2012) and are diffused among family-based companies (Looser and Wehrmeyer 2015) - mark Costa Edutainment strategic behavior and render it a unique group in Italy capable of guaranteeing a high local commitment and a strong positive economic repercussions in the areas where it operates.

In accordance to its mission, the group decided to improve the communication of the sustainability orientation by starting the journey toward the integrated report. The initial idea which lead Costa Edutainment to consider

Table 3 The guiding principles of the entrepreneurial action

\begin{tabular}{|c|c|}
\hline The centrality of the visitor & $\begin{array}{l}\text { "We listen to the needs of our visitors to improve the quality of their visit experience } \\
\text { over time". }\end{array}$ \\
\hline $\begin{array}{l}\text { Commitment to the welfare of animals and the } \\
\text { natural environment }\end{array}$ & $\begin{array}{l}\text { "We contribute to directly and indirectly promoting and preserving the welfare of } \\
\text { animals and safeguarding of natural global environment". }\end{array}$ \\
\hline Collaboration and valorization of people & $\begin{array}{l}\text { "We create a collaborative-based organizational climate and external environment } \\
\text { based on the valorization of people". }\end{array}$ \\
\hline Attention to profit as a tool for a responsible growth & $\begin{array}{l}\text { "We believe that profit is an essential factor for the company's development, not only } \\
\text { in the interest of shareholders but also as an instrument to support the Company's } \\
\text { responsibility towards the territory in which it operates". }\end{array}$ \\
\hline Support to the territories where we are present & $\begin{array}{l}\text { "We have always collaborated with national and international Public Administrations } \\
\text { as well as the local and territorial system of public and private organizations". }\end{array}$ \\
\hline Focus on scientific research & $\begin{array}{l}\text { "We deepen and update our scientific and cultural expertise in the areas where we } \\
\text { operate and are recognized as a national excellence". }\end{array}$ \\
\hline Fairness in dealing with suppliers & "We treat suppliers as partners on a shared path". \\
\hline
\end{tabular}


publishing an integrated report, arose in fact from the need to systematize different corporate sustainabilitydriven actions and results, which had never previously been accounted for consistently, in order to manage, interpret and communicate the overall economic, social and environmental value created for all stakeholders in the short, medium and long-term.

"The identity of the company which operates primarily in the scientific and cultural sector followed by the tourism sector, has developed since the beginning on the basis of values of responsibility towards people, the environment and society" (CSR Officer and external relations manager, April, 2016).

The journey was based on a fundamental steps: "preparing the journey", "making the journey" and "talking about the journey". It was triggered by the creation of a specific working group lead by an internal project manager (CSR Manager) and formed of the owner-entrepreneur, firstlevel managers (Chief Executive Officer, Human Resource Manager, Marketing Manager, internal Staff Audit and a Scientific Director) and external consultant in preparing an action plan aimed to critically evaluate the business model and improve the connectivity among capitals, stakeholders and corporate objectives. Connectivity has been referred to the four dimensions of the business model (Table 4). To clearly express the fundamental strategic direction towards the creation of economic, social and environmental value, a strategic map has been outlined inspired by the balanced scorecard model and integrated with the stakeholder oriented approach and the six capitals model proposed by the IIRC Framework (IIRC 2013).

The capitals include the following categories of resources.

Productive capital: founded on: a continue renewal of the offer, the use of e-commerce and the development of

Table 4 Costa Edutainment's business model dimensions

\begin{tabular}{ll}
\hline Dimension & Content \\
\hline Input & $\begin{array}{l}\text { The resources (capitals) available to the } \\
\text { company to carry out strategic objectives } \\
\text { (financial, productive, organizational, human, } \\
\text { relational, social and natural resources). }\end{array}$ \\
$\begin{array}{ll}\text { Objectives/organizational } & \text { Improvement goals related to the processes } \\
\text { processes } & \text { have been grouped together into four areas } \\
& \text { of value creation: governance and } \\
& \text { transparency, relations with key stakeholders, } \\
& \text { economic and financial sustainability and } \\
\text { environmental protection. } & \\
\text { Stakeholders } & \text { not just clients, as in a traditional perspective, } \\
& \text { but an extended series of interlocutors } . \\
\text { Performance } & \text { Corporate results referring to capital } \\
& \text { typologies. }\end{array}$ \\
\hline
\end{tabular}

Source: Costa Edutainment Integrated Report, 2014: 37 social media team and web platforms; and the attention to promote sustainable food and beverage.

Natural Capital: intended as the continuous engagement in reduction of resources (water, energy and $\mathrm{CO} 2$ ). For instance, the Genoa Aquarium has been investing to optimize the water filtration lines of the tanks, replacing pumps motors with high efficiency engines, use disinfection systems with a reduced environmental impact and optimizing waste recycling. Moreover, the attention to biodiversity preservation mirrors in a lot of projects in collaboration with Costa Foundation aimed to manage more than 800 different animal species (such as turtles, cetaceous and dolphins) and save endangered species.

Human capital: centered on the evaluation of persons, talents and competences, training and people engagement.

Organizational capital: based on the optimization of resources within the Group.

Relational capital: based on the renewal of the relationship with visitors, also through the storytelling and the direct engagement of visitors.

The integrated reporting path has been developing within the Industrial 2015-2020 plan and is oriented to implementing the principle of integrated thinking, improve connectivity among the dimensions of the business models, enhancing disclosure, monitor performance and strengthening stakeholder engagement on sustainable strategic issues and objectives (Table 5 and Graph 1 ). The evolving process has contributed to highlighting the macro-categories of corporate interlocutors, which include: clients, employees, local bodies, shareholders, financers, suppliers, trade unionists, the environment, animals, the scientific community, NGOs, pressure groups, citizens, local communities, national and international institutions, business partners and competitors. Among these, three categories are particularly important for strengthening the processes of stakeholders' listening and dialogue: 1) personnel (employees, collaborators and external personnel that carry out services within the structures); 2) clients (especially schools to which companies have always dedicated specific didactic projects, often co-planned with the teachers); and 3) local public authorities, that are among the main actors of territorial governance.

"To reach the formulation of a materiality matrix, we started the first year with stakeholder mapping (2014), then moved on to the definition of relevant issues according to the internal managerial perspective (2015). The 2016 programme envisages stakeholder engagement aimed at forming a Matrix" (Mixura Srl-External Partner \& CSR Officer, April 2016).

The integrated reporting process generated both internal and external benefits. The former include an 
Table 5 Costa Edutainment's KPIs and results on the capitals

\begin{tabular}{|c|c|}
\hline Capitals & KPls \\
\hline Financial capital & $\begin{array}{l}\text { The savings rate from service optimization outsourcing } \cdot \text { Turnover } \cdot \text { Profits } \cdot \text { Cash flow } \\
\cdot \text { - Average turnover per employee } \cdot \text { Average cost per employee } \cdot \text { Distribution of added value }\end{array}$ \\
\hline Productive capital & - Completion of cetacean stand $\cdot$ New exhibits $\cdot$ Restoration of National Antartic Museum \\
\hline Organizational capital & $\begin{array}{l}\text { - Web platform for integrated reporting } \boldsymbol{~} \text { Reorganization of aquarium sector } \boldsymbol{~} \text { Establishment } \\
2014-2018 \text { Industrial Plan } \boldsymbol{~ C o r p o r a t e ~ m a n a g e m e n t ~ s y s t e m ~}\end{array}$ \\
\hline Human capital & $\begin{array}{l}\text { Number and type of tables for collaborative processes: } \cdot \text { Total hours of training } \cdot \text { Average } \\
\text { hours of training } \cdot \text { Percentage of employees that have done training courses } \cdot \text { Turnover } \\
\cdot \text { Total number of employees } \cdot \text { Average age } \cdot \text { Schooling } \cdot \text { Number of women } \cdot \text { Number of } \\
\text { work accidents } \cdot \text { Seniority } \cdot \text { Application of second level contract }\end{array}$ \\
\hline Relational/social capital & $\begin{array}{l}\text { Euro number of projects sustained for cultural and social purposes } \cdot \text { Activity "Aquarium } \\
\text { friends" } \cdot \text { Customer Satisfaction Index } \cdot \text { Feedback from social network } \bullet \text { Complaints } \\
\text { management, press office } \cdot \text { Educational efficacy } \cdot \text { Results of school project } \bullet \text { Presence in } \\
\text { national and foreign trade fairs } \cdot \text { Percentage of visitors to the structures }\end{array}$ \\
\hline Natural Capital & $\begin{array}{l}\text { - Number and type of scientific research project } \cdot \text { Energy consumption (water, electricity and } \\
\text { gas) } \cdot \text { Biodiversity } \text { - Bioethics }\end{array}$ \\
\hline
\end{tabular}

Source: Costa Edutainment Integrated Report, 2014: 40

assessment of intangibles and improvement in cohesion of the company culture thanks to a stratification at all levels of a clear knowledge of the company, its strategies and results, previously communicated in a fragmented way or not totally communicated (internal disclosure). The main external benefits include an improvement in the company's visibility in financial, academic and institutional national and international contexts.

"We have succeeded in creating an orderly and structured value system of some intangibles (in particular those concerning relational capital) which previously had not been correctly placed within the values creation model and were seen as corporate choices, sometimes 'erratically' made" (Mixura Srl-External Partner \& CSR Officer, April 2016).
The company's models of value creation (Fig. 1) highlights for each of the areas below presented the optimal development of those processes (integrated reporting, corporate citizenship, the supply-chain, energy efficiency and so on) through which the company transforms resources (divided into six input capitals) into value (output capitals).

Governance and transparency: the company is aware that the consolidation of a clear positioning as responsible company necessarily requires a strengthening of disclosure processes which rests on a gradual and lengthy evolution of the company culture. In particular, the monitoring of economic, financial, social and environmental objectives presupposes a reliable business reporting capable of stimulating information sharing and collaboration with stakeholders.

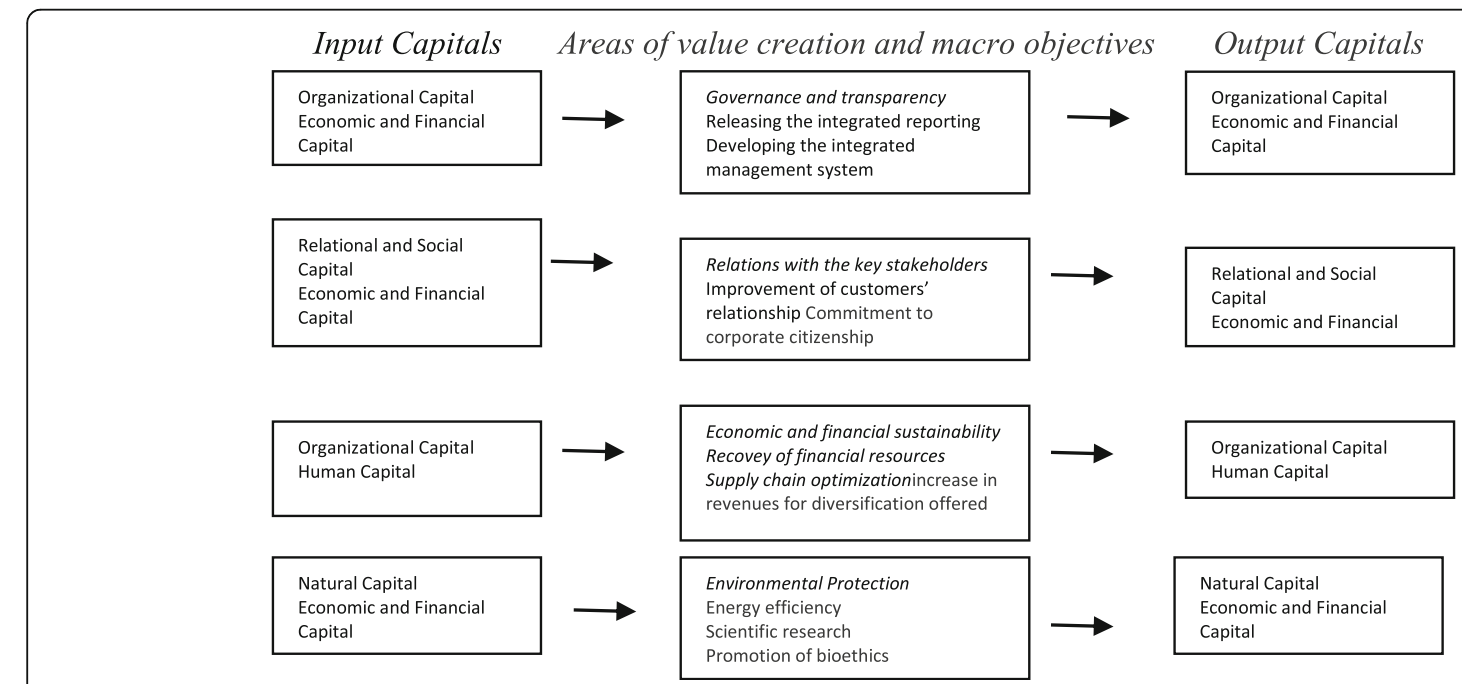

Fig. 1 Costa Edutainment's model of value creation and connection with capitals. Source: our elaboration from Costa Edutainment Integrated Report, 2014: 38 
Relations with key stakeholders: the valuing of relations with clients, collaborators and local institutions is an integral part of the set of values promoted by the Costa family and shared within the company. However, the relational system with key stakeholders is not yet homogenous. Whilst the centrality of the client and local institutions has been translated in many actions and policies, the relationship with employees should be further enhanced. According to this aim, the future vision aims to improve operative tools to guarantee a higher level of safe working environment, value individual talent and strengthen team work. Moreover, with regard to customers relationships, Costa Edutainment aims at innovating sensitivity of its suppliers in order to restructure and co-plan demand. Finally, in relation to the institutions, it intends to further develop shared territorial projects capable of bringing value to the company and the local areas.

Economic and financial sustainability: Costa Edutainment is committed to improving its profitability both through the optimization of existing processes (i.e. the renegotiation of relations with banks; the harmonization of control systems at group level; the redefinition of outsourcing contracts), and the development of new sources of revenue. For the future (2015-2017) the company is committed to maximize the economic value generated from existing structures and monitor rating models proposed by ethical finance operators who are attentive to social and environmental performance.

Environmental Protection: the company is actively involved in improving environmental protection (through the minimization of the impact of its structures on the environment and the promotion of bioethical standards for sheltered animals) and indirect protection (through awareness-raising and environmental education for the general public). Taking care of the environment also includes the certification of the management system and the politics for quality, environment and security in accordance to the national and international standard (UNI EN ISO 9011, 14,001 and OHSAS 18001).

\section{The pillars of sustainability in Costa Edutainment}

The four main drivers which characterize Costa Edutainment's commitment to sustainability, understood in the broader sense as a corporate commitment driven by ethical principles and values shared with stakeholders, are: 1) the company's citizenship on the territory; 2) stakeholder listening and dialogue; 3 ) the respect of the environment and biodiversity and 4) the responsible use of energy.

\section{The company's citizenship on the territory}

Costa Edutainment has always been strongly committed to the development of the territories it belongs to. This object has been achieved through an intense cooperation with local governments, social cause support and the active participation of the entrepreneur and top managers in the world of trade associations, non-profit and NGO organizations which has been concretized by triggering several public-private partnerships which represent an effective way for acting in a competitive and responsible way in the tourism context (Zapata and Hall 2012).

\section{Stakeholder listening and dialogue}

Dialogue and co-designing services with visitors are central features of the company strategy. Listening to the customer's point of view, commitment to a quick response in regards to suggestions and complaints, the quality of life and work for employees, as well as the transparency in commercial offerings are not considered a due act, but the tangible demonstration of respect for the visitor's point of view and expectations.

\section{Respect for the environment and biodiversity}

Awareness raising and education to respect for nature and the protection of biodiversity are the core values of Costa Edutainment action. The company has always been putting skills to enhance the multi-stakeholder network system, including local, national and international public and private institutions, universities and research centers to develop environmental education, research and conservation projects.

\section{The responsible use of the energy and resource}

Many group structures, especially aquariums, are definitely "big energy consumers". Accordingly, the company is committed to enhance the energy within its main facilities, in order to significantly slow down the environmental impacts and pursue economic savings through several projects of energy diagnosis and optimization.

\section{Some examples of Costa Edutainment's sustainable projects}

Starting from the awareness to preserve the global environment and to actively contribute to European marine biodiversity which is under severe threat from a range of pressures including pollution, climate change and ocean acidification, overexploitation of marine resources and invasive alien species (EEA 2010), in 2015 Costa Edutainment started the Sea For Society (SFS) project. The project was included in the Funding Scheme Mobilization and Mutual Learning and was supported by the EU financial contribution. It involved twenty partners and eight associated partners belonging to twelve Countries.

The SFS project was a concrete answer to an ever increasing need to ensure the sustainable management of marine ecosystem services whilst taking into 
consideration society's need for a progressive and thriving economic development. It was aimed at developing an ambitious vision for the whole society, embracing the spirit of sustainability, well-being and equity for humankind as its guiding principle. This vision is in harmony with the ocean and capable to develop a Blue Society, based on the pillars and expected impacts summarized in the following table (Table 6). Under the Marine Strategy Framework Directive, all EU countries have committed to achieve a good environmental status in their marine waters by 2020 . The EU's blue economy represents 5.4 million jobs and a gross added value of just under $€ 500$ billion per year. By 2020 the EU hopes to increase this to 7 million jobs and $€ 600$ billion a year.

\section{The learning \& education activities: some examples}

Among the Costa Edutainment's facilities, the Aquarium of Livorno (Tuscany) approaches to the world of education created by the Educational Department of Costa Edutainment S.p.A follows the principle of educational entertainment, by privileging a deductive approach to learning and catering a multi grade offer of educational activities. Activities, ranging from guided to themed tours and from didactical laboratories to the special project 'Behind the scenes', are consistent with the Aquarium mission that is focused on increasing environmental awareness to protection and knowledge of the environment (in particular the marine environment) among the general public and young generations.

Table 6 The Sea For Society project

Pillars
Bringing together different stakeholders: (economic
stakeholders, environmental organizations, local
authorities, the public-at large, and youth) with
complementary knowledge and experiences to
forge new partnerships using a participatory
approach resulting in public engagement in
research.
Setting up a consultation process across Europe to
facilitate dialogue and cooperation between
different stakeholders, citizens and youth to identify
challenges and barriers of coastal and marine
ecosystem services in relation to societal needs
and propose challenge-driven solutions.

Sharing the co-authored knowledge arising from the dialogue process in a broad and effective manner in order to empower stakeholders, citizens and youth to take action to tackle the societal challenges identified.

Providing advice to inform and support research policy in order to optimise the role of research and technology in tackling marine resources, inland activities and sustainable development.

Developing and enriching the concept of a Blue Society as a basis for improved governance of the Ocean.

Developing ongoing mechanisms such as partnership, interaction, public-research engagement to ensure the sustainability of the Sea For Society process, ultimately resulting in empowerment actions to address marine societal challenges.

\section{Expected Impacts \\ Involved Partner}

Increase European stakeholders, citizens and youth awareness of the relevance of the ocean to their daily lives.

Lead to further empowerment of stakeholders, citizens and youth to take action at a local, national and European level to tackle marine societal challenges.

Improve Research \& Development and marine and maritime governance at regional, national and European levels.

Define the social, economic, environmental and cultural pillars of the Blue Society throughout the partnership of stakeholders, citizens and youth.

Foster an integrated vision towards a sustainable use of marine ecosystems services and a balanced use of marine resources. Spain
Nausicaá National Sea Centre, France EurOcean Foundation, Portugal IOPAN, Institute of Oceanology of the Polish Academy of Sciences, Poland AquaTT UETP Ltd., Ireland

UGOT, University of Gothenburg, Sweden Ciência Viva - National Agency for Scientific and Technological Culture, Portugal IEO, Spanish Institute of Oceanography,

ADG, Costa Edutainment S.p.A., Italy Mc2, Aquarium Finisterrae - Science Museums of Coruña, Spain

Marine Institute, Ireland

Hellenic Centre for Marine Research, Greece Institute of Marine Research, Norway Marine Environment and Technology Center of Instituto Superior Técnico, Portugal

The European Network of Science Centres and Museums, Belgium

International Union for Conservation of Nature- European Regional Office, Belgium European Business \& Innovation Centre Network, Belgium

NUI Galway-National University of Ireland, Galway, Ireland

World Ocean Network, Belgium

French Research Institute for Exploitation of the Sea, France

Studio K SARL, France

Associated Partners

IUCN France-International Union for Conservation of Nature - French Committee, France

IUCN Spain - International Union for Conservation of Nature - Spanish Committee, Spain

MadaTech - The Israel National Museum of Science, Technology \& Space; Daniel and Matilde Recanati Center, ISRAEL

IRScNB-Royal Belgian Institute of Natural Sciences, Belgium

National Natural History Museum, France NHM- Natural History Museum, United Kindgdom

W5-Whowhatwherewhenwhy, Interactive Discovery Centre, Northern Ireland Flanders Marine Institute, Belgium. 
The Educational and Cultural Department aims to be an authentic reference point for all teachers intending to include a visit to the Aquarium in their annual teaching program, offering experts and projects including workshop activities. During the course of each project students are able to investigate a wide range of topics by means of direct experiences and use special instruments, such as the Laboratory Scientists dedicated to primary schools. Students are active participants in observing, comparing and thinking with the aim of enhancing a proactive behavior towards environmental conservation and protection. Related to the vast spectrum of edutainment activities, Costa has received a number of awards (Table 7).

The Aquarium Foundation ONLUS was founded in 2003 and is committed to raising awareness and educating people for the conservation and responsible use of environments through the knowledge of animal species and their habitats. In addition to Costa Edutainment, the founders include the Municipality of Genoa, the Province of Genoa, the University of Genoa and the World Ocean Association, whose representatives are part of the Board. The purpose of the Foundation is to protect and enhance the environment, with particular reference to aquatic environments, through dissemination and education activities at the general public, awareness-raising actions against public institutions and private entities, implementation of applied scientific research projects, participation in active safeguards for endangered aquatic ecosystems in various areas of the world.

\section{Discussion and conclusive remarks}

Costa Edutainment's business model is characterized by a structured commitment to the development of the territories that host the structures of the Group. This feature has favored the implementation of responsibledriven and sustainability-oriented projects in the tourism sector which is particularly sensitive to environmental issues, since environment is a pillar of both its business model and the sector the company belongs to (Kalisch 2002; Brent Ritchie and Crouch 2003). In addition, Costa

Table 7 Awards and Recognitions obtained in 2016

\begin{tabular}{ll}
\hline Golden Seals & $\begin{array}{l}\text { Assigned for the second year for the service } \\
\text { quality provided to consumer through three } \\
\text { facilities of the Costa Group. }\end{array}$ \\
$\begin{array}{l}\text { First prize as "Best } \\
\text { Educational Event" }\end{array}$ & $\begin{array}{l}\text { Received at the Best Event Awards 2016, the } \\
\text { main event dedicated to the Italian Event } \\
\text { Industry }\end{array}$ \\
Parksmania Awards & $\begin{array}{l}\text { The Aquarium of Genoa has been awarded for } \\
\text { the project "Overseas Regeneration". }\end{array}$ \\
& $\begin{array}{l}\text { The Aquafan Park has been included in the } \\
\text { Nominations for categories "Best Personal" } \\
\text { and "Best Show Outdoor". }\end{array}$ \\
\hline
\end{tabular}

Edutainment has a particular aptitude and ability to handle public goods in collaboration with the public and private institutions and, more general, the local actors that are part of the areas where the facilities are located (Hall 1999, 2008; Zapata and Hall 2012). This feature is part of the company's identity and forges its business model that is driven toward strong sustainability (Ayres et al. 1998). Notably, it derives from core values that have been inherited from the entrepreneurial family through generations (Looser and Wehrmeyer 2015; Del Baldo and Baldarelli 2017). Moreover, it is tied to its social capital, that is the systems of values, norms and behaviors that the entrepreneur ant the top management share with the stakeholders (Del Baldo, 2014). The business is thus interpreted as a 'tool' to generate returns in terms of responsible tourism, improved well being of the people (starting from employees and customers), the local and global communities, and the environment (Bocken et al. 2014; Schaltegger et al. 2012; Thompson et al. 2015). In other words, the company acts an actor involved in contributing to the integral development of the local and global context (Sorci 2007; Schieffer et al., 2014; Jakobsen et al. 2017). Accordingly, the choice to implement the integrated reporting is tied to the will to disclose its value proposition and the effects of its strategy of value creation (Bebbington 2007; Simaens and Koster 2013).

Being a private company to manage a public good - a circumstance that is frequent within the tourism sector where public and private "mixture" are increasingly widespread (Hall 2008) - requires to extend the strategic focus and revise the business model by integrating a 'collective benefit' (the so called common good) among the company expected outcomes, engaging internal and external stakeholders in generating value (Seelos and Mair 2005, 2006; Johnson 2010; Patzelt and Shepherd 2011). In the tourism sector, which is intrinsically tied to natural and cultural resources, this underlines the need to set up sustainable business models, as per the experience of Costa Edutainment that has often been publicly recognized as a best practice from institutional partners.

\section{"We are proud to have had the opportunity to collaborate with many public and private actors over the years and with some of them we work every day to build the cultural and tourist identity of our territories" (CEO and President of Costa Edutainment, April 2016).}

Over the years, the goals set out in the industrial plans have lead Costa Edutainment to increase the commitment on three main fronts: the consolidation of the presence within the scientific community; the centrality of the person; the energy efficiency and reduction of consumption. These strategic lines characterize the 
sustainable business model that drives the company to act as a responsible and relation-based company, focused on the creation of sustainable value in the short, medium and long term (Tukker et al. 2008; Dyllick and Hockerts 2002; Salzmann et al. 2005; Schaltegger et al. 2012; Stubbs and Cocklin 2008).

In accordance to the aforementioned strategic objectives, both the development of new business areas and territorial networks with the scientific community have never been decupled from the basic principal of the centrality of people (employees, collaborators and visitors) and the preservation of the natural environment, both directly (through the efficiency in use of resources) and indirectly, improving the educational vocation. This latter is aimed to cultivate the awareness and involvement of people in protecting the environment through learning \& education, and stakeholder engagement activity (Visser 2011; Dean and McMullen 2007; Hall et al. 2010).

On the basis of the findings emerged from the caseanalysis, one can affirm that Costa Edutainment is promoting a project of education and cultural evolution which is a pre-conditions for a genuine proposal of responsible and sustainable tourism. This reflection, which emerges from the current state of the study, may be further deepened through future research steps. Indeed, the study presents two main limitations: on the one hand it is centered on a single case study and we are aware that the single case study approach precludes generalization. On the other hand, evidences should be corroborated by monitoring Costa's strategies in a medium-time perspective. Being the strong sustainability orientation connected to a medium-long perspective a constant monitoring of Costa's strategies should be performed over several years. In this regard, a subsequent and a more in-depth investigation involving Costa's internal and external stakeholders could be of benefits to assess the improving of both the business models and the accountability tools. Finally, a comparative analysis could be useful, adopting a multiple case-study approach. The afore mentioned limitations of research could thus be amended through further research effort. Nevertheless, despite the aforementioned limitations, the results derived from the study have both scientific and managerial implications, because they underline the key role tourism and cultural operators play in orienting people towards sustainability acting as an 'incubator' of environmental culture and a mediator in promoting a culture of sustainability within the local, national and international community. In particular, results emphasize the relevance of a strong sustainability approach applied in tourism and education, founded on a set of ethical values and the benefits to the local and global community. Moreover, being Costa's choice to drawing up the integrated report an answer to a cultural and ethical incentive relative to the vocation to edutainment the case could be of interest to a number of parties including other tourism companies, public authorities and research institutions, since it evidence the challenges encountered in pursuing strong sustainability and the potential implications for the business model and multidimensional (financial, social, ethical and environmental) performances.

\section{Acknowledgments}

We would like to thank the following for their invaluable collaboration, sensitivity and help in providing us with the material necessary to develop the analysis of the case and share our reflections: the Costa's external consultant partner (Mixura Srl), the CSR Officer and external relations Manager and the President \& CEO of Costa Edutainment.

The paper has been presented at the 4th International Conference on CSR, Sustainability, Ethics \& Governance, "Responsible Business for Uncertain Times and a Sustainable Future", held on 26-28 July 2017, in Perth, Western Australia, Track: CSR in Business Education; CSR in Tourism; New Sustainable Business Models.

\section{Funding}

I received from Marina Schmitz the fee waiver code for the JCSR.

Hoping that it could be considered interesting for your prestigious journal, and looking forward to receive the reviewers comments,

Sincerely.

Author's contributions

The author read and approved the final manuscript.

Competing interests

The author declares that he/she has no competing interests.

\section{Publisher's Note}

Springer Nature remains neutral with regard to jurisdictional claims in published maps and institutional affiliations.

Received: 8 November 2017 Accepted: 30 January 2018

Published online: 27 February 2018

\section{References}

Abdelkafi, N., \& Täusher, K. (2015). Business models for sustainability from a system dynamics perspective. Organization Environment. https://doi.org/10. $1177 / 1086026615592930$.

Adams, C. (2002). Internal organizational factors influencing corporate social and ethical reporting. Accounting, Auditing and Accountability Journal, 15(2), 223-250.

Almers, E. (2013). Pathways to action competence for sustainability - six themes. The Journal of Environmental Education, 44(2), 116-127.

Ayres R.U., van den Bergh, J. \& Gowdy, J.M. (1998). Viewpoint: Weak versus strong sustainability. Center for the Management of environmental resources. Accessed 27 Dec 2017 at. http://kisi.deu.edu.tr/sedef.akgungor/ayres.pdf.

Bebbinghton, J. (2007). Accounting for sustainable development. Oxford: CIMA.

Bellman, R., Clark, C. E., Malcolm, D. G., Craft, C. J., \& Ricciardi, F. M. (1957). On the construction of a multi-stage, multi-person business game. Operations Research, 5, 469-503 https://doi.org/10.1287/opre.5.4.469.

Benbasat, I., Goldstein, D. K., \& Mead, M. (1987). The case research strategy in studies of information-systems. Mis Quarterly, 11, 369-386.

Bocken, N., Short, S., Rana, P., \& Evens, S. (2014). A literature and practice review to develop sustainable business mode archetypes. Journal of Cleaner Production, 65, 42-56.

Boons, F., \& Lüdeke-Freund, F. (2013). Business models for sustainable innovation: state-of-the-art and steps towards a research agenda. Journal of Cleaner Production, 45, 9-19.

Brent Ritchie, J. R., \& Crouch, G. I. (2003). The competitive destination: a sustainable tourism perspective. Trowbridge: Cromwell Press.

Budeanu, A. (2009). Environmental supply chain management in tourism: The case of large tour operators. Journal of Cleaner Production, 17(16), 1385-1392.

Cape Town Declaration. (2002). International conference on responsible tourism in destinations. Cape Town: The Cape Town Declaration. 
Cater, C. (1993). Ecotourism in the third world: problems for sustainable tourism development. Tourism Management, 14(2), 85-90. https://doi.org/10.1016/ 0261-5177(93)90040-R.

Clifton, J., \& Benson, A. (2006). Planning for sustainable ecotourism: the case for research ecotourism in developing country destination. Journal of Sustainable Tourism, 14(3), 238-254

Coles, T., Fenclova, E., \& Dinan, C. (2013). Tourism and corporate social responsibility: a critical review and research agenda. Tourism Management Perspective, 6, 122-141.

Costa Edutainment (2014). Integrated report 2014. Genova. www. costaedutainment.it.

Costa Edutainment (2015). Integrated report 2015. Riccione (IT). http://www. costaedutainment.it/wp-content/uploads/2017/04/RI_COSTA_2016_31_03_ 2017.pdf.

Costa Edutainment (2016). Costa edutainment experience, integrated report. Riccione (IT)

Dean, T. J., \& McMullen, J. S. (2007). Toward a theory of sustainable entrepreneurship: Reducing environmental degradation through entrepreneurial action. Journal of Business Venturing, 22, 50-76

Del Baldo, M. (2012). Familial and territorial values for sustainable entrepreneurship in Italy: Some reflections in theory and practice. Journal of Modern Accounting and Auditing, 8(8), 1185-1203.

Del Baldo, M. (2014). To the Roots of Entrepreneurial Values: The Relationship with the Territory as a Driver for the Development of Corporate Social Responsibility - An Analysis of the Experiences of Italian SMEs. In Yüksel Mermod, A. \& S. O. Idowu, S.O. (Eds.), Corporate Social Responsibility in the Global Business World. Springer-Verlag Berlin Heidelberg (pp. 169-189).

Del Baldo, M. (2017a). CSR, shared territorial governance and social innovation. Some exemplary Italian paths. In N. Capaldi, S. Idowu, \& R. Schmidpeter (Eds.), Dimensional corporate governance. An inclusive approach (pp. 103-120). Cham: Springer International Publishing AG. https://doi.org/10.1007/978-3-319-56182-0_7.

Del Baldo, M. (2017b). The implementation of integrating reporting $\langle\mathrm{R}\rangle$ in SMEs. Insights from a pioneering experience in Italy. Meditari Accountancy Research, 25(4), 505-532 https://doi.org/10.1108/MEDAR-11-2016-0094.

Del Baldo, M., \& Baldarelli, M. G. (2017). Renewing and improving the business model toward sustainability in theory and practice. International Journal of Corporate Social Responsibility, 2(3), 1-13. Springer Open. https://doi.org/10. 1186/s40991-017-0014-z

Dodds, R., \& Joppe, M. (2005). CSR in the tourism industry? The status of and potential for certifications, codes of conduct and guidelines, Foreign investment advisory service investment climate department. Washington: IFC/World Bank.

Dumay, J., \& Dai, T. (2017). Integrated thinking as a cultural control? Meditari Accountancy Research, 25(4), 574-604 https://doi.org/10.1108/MEDAR-072016-0067.

Dyllick, T., \& Hockerts, K. (2002). Beyond the business case for corporate sustainability. Business, Strategy and Environment, 11(2), 130-141.

EEA -European Environemntal Agency. (2010). Report no 5, assessing biodiversity in Europe, 1 October 2010. EEA, Luxembourg: Office for Official Publications of the European Union.Copenhagen, Denmark https://www.eea.europa.eu/.

Eisenhardt, K.M. (1989). Building theories from case study research. Academy of Management Review, 14(4), 532-550.

Eisenhardt, K. M., \& Graebner, M. E. (2007). Theory building from cases: Opportunities and challenges. Academy of Management Journal, 50(1), 25-32.

Garriga, E., \& Melé, D. (2004). Corporate social responsibility theories: mapping the territory. Journal of Business Ethics, 53(1), 51-71.

Hall, C. M. (1999). Rethinking collaboration and partnership: A public policy perspective. Journal of Sustainable Tourism, 7, 274-289.

Hall, C. M. (2008). Tourism planning processes and relationships (2nd ed.). Harlow: Prentice-Hall.

Hall, J. K., Daneke, G. A., \& Lenox, M. J. (2010). Sustainable development and entrepreneurship: Past contributions and future directions. Journal of Business Venturing, 25(5), 439-448.

Hartwick, J. (1977). Intergenerational equity and the investing of rents from exhaustible resources. American Economic Review, 67, 972-974.

Hartwick, J. (1978). Substitution among exhaustible resources and intergenerational equity. Review of Economic Studies, 45, 347-354.

Hartwick, J. (1990). Natural resource accounting and economic depreciation. Journal of Public Economics, 43, 291-304.

Herzig, C., Viere, T., Schaltegger, S., \& Burritt, R. (2012). Environmental management accounting. Case studies of south-east Asian companies. London: Routledge.

IIRC. (2013). The international $<I R>$ framework. London: The International Integrated Reporting Council.
Jakobsen, O., Zolnai, L., \& Chatterji, M. (Eds.). (2017). Integral ecology and sustainable business, Series contributions to conflict management, peace economics and development (Vol. 26). Bingley: Emerald Publishing.

Johnson, M. W. (2010). Seizing the white space. In: Business model innovation for growth and renewal. Boston: Harvard Business School Press.

Kalisch, A. (2002). Corporate futures, social responsibility on the tourism industry. London: Tourism Concern.

Linder, J. C., \& Cantrell, S. (2000). Changing business models: Surveying the landscape. Cambridge: Accenture Institute for Strategic Change. http://course shufe.edu.cn/jpkc/zhanlue/upfiles/edit/201002/20100224120954.pdf.

Looser, S., \& Wehrmeyer, W. (2015). Doing well or doing good? Extrinsic and intrinsic CSR in Switzerland, UWF, 1-14, published on line august 14, 2015. Berling Heidelberg: Springer-Verlag. https://doi.org/10.1007/s00550-015-0360-9.

Lüdeke-Freund, F. (2009). Business model concepts in corporate sustainability contexts. In from rhetoric to a generic template for business models for sustainability. Lüneburg: Centre for Sustainability Management.

Manente, M., Minghetti, V., \& Mingotto, E. (2014). Responsible tourism and CSR. Switzerland: Springer International Publishing.

Martìnez, P. \& Rodriguez del Bosque, I. (2013). CSR and customer loyalty; the roles of trust, customer identification of sustainable criteria. International Journal of Hospitality Management, 35, 89-99.

Medina, L. K. (2005). Ecotourism and certification; confronting the principles and pragmatics of socially responsible tourism. Journal of Sustainable Tourism, 13(3), 281-295

Miller, G. (2001). Corporate responsibility in the UK tourism industry. Tourism Management, 22(6), 589-598.

Novak, A. (2014). Business model literature overview. Financial Reporting, 1, 79-130 https://doi.org/10.3280/FR2014-001004

Osterwalder, A., Pigneur, Y., \& Tucci, C. (2005). Clarifying business models: Origins, present and future of the concept. Communications of the Association for Information Systems, 15, 1-38.

Patton, M. Q. (2002). Qualitative Research \& Evaluation Methods (3rd ed.). Thousand Oaks: Sage Publications

Patzelt, H., \& Shepherd, D. A. (2011). Recognizing opportunities for sustainable development. Entrepreneurship Theory and Practice, 35(4), 631-652.

Responsible Travel Handbook (2006), http://www.transitionsabroad.com/listings/ travel/responsible/responsible_travel_handbook.pdf, www.costaedutainment. it. Accessed 22 Sept 2013

Ryan, B., Scapens, R.W. \& Theobald, M. (2002). Research method \& methodology in finance \& accounting, 2nd ed. London: Thomson.

Salzmann, O., lonescu-Somers, A., \& Steger, U. (2005). The business case for corporate sustainability: Literature review and research options. European Management Journal, 23(1), 27-36.

Sankaran, S., \& Tay, B. H. (2003). Action research models in business research. East Lismore: Southern Cross University, Institute of Action Research.

Schaltegger, S., \& Wagner, M. (2011). Sustainable entrepreneurship and sustainability innovation: Categories and interactions. Business Strategy and the Environment, 20, 222-237.

Schaltegger, S., Lüdeke-Freund, F., \& Hansen, E. G. (2012). Business cases for sustainability: The role of business model innovation for corporate sustainability. International Journal of Innovation \& Sustainable Development, $6(2), 95-119$

Schaltegger, S., Hansen, E. G., \& Lüdeke-Freund, F. (2016). Business models for sustainability: Origins, present research, and future avenues. Organization \& Environment, 29(1), 3-10.

Schieffer, A., \& Lessem, R. (2014). Integral development: Realising the transformative potential of individuals, Organisations and societies. Aldershot: Gower Publishing.

Seelos, C., \& Mair, J. (2005). Social entrepreneurship: Creating new business models to serve the poor. Business Horizons, 48, 241-246.

Seelos, C., \& Mair, J. (2006). Social entrepreneurs e the contribution of individual entrepreneurs to sustainable development, The ICFAl journal for entrepreneurship development (pp. 30-46).

Simaens, A., \& Koster, M. (2013). Reporting on sustainable operations by third sector organizations. Public Management Review, 15(7), 1040-1062.

Solow, R. (1974). The economics of resources and the resources of economics. American Economic Review, 64, 1-14.

Solow, R. (1986). On the intergenerational allocation of natural resources. Scandinavian Journal of Economics, 88(1), 141-149.

Solow, R. (1993). An almost practical step toward sustainability. Resources Policy, 2, $162-172$

Sorci, C. (2007). Lo sviluppo integrale delle aziende. Milano: Giuffré 
Sorrentino, M., \& Smarra, M. (2015). The term "business model" in financial reporting: Does it need a proper definition? Open Journal of Accounting, 4, 11-22 https://doi.org/10.4236/ojacct.2015.42002.

Stubbs, W., \& Cocklin, C. (2008). Conceptualizing a 'sustainability business model'. Organization \& Environment, 21, 103-127.

Tamajòn, L. G., \& Font Aulet, X. (2013). Corporate social responsibility in tourism small and medium Enterprise. Evidence from Europe and Latin America. Tourism Management Perspective, 7, 38-46.

Tapper, R. (2001). Tourism and socio-economic development: UK tour operators business approaches in the context of the new international agenda. International Journal of Tourism Research, 3, 351-356.

Thompson, N. A., Herrman, A. M., \& Hekkert, M. P. (2015). How sustainable entrepreneurs engage in institutional change. Insights from biomass torrefaction in the Netherlands. Journal of Cleaner Production, 106, 608-618.

Tukker, A., Charter, M., Vezzoli, C., Stø, E., \& Andersen, M. M. (Eds.). (2008). Perspectives on radical changes to sustainable consumption and production. Sheffield: Greenleaf.

UNEP. (2005). Making tourism more sustainable - a guide for policy makers. Paris: United Nations Environmental Program (UNEP) World Tourism Organization (WTO).

UNWCED. (1987). United nation world commission on environment and development, Brundtland report. Our common future. Oxford: Oxford University Press.

UN-WTO. (1993). UN-world tourism organization, Sustainable tourism development: Guide for local planners. Madrid: World Tourism Organization, 1993.

Visser, W. (2011). The nature of CSR leadership. Definitions, characteristics and paradoxes. CSR International Paper Series, 4, 1-10.

Yin, R. K. (2003). Case study research. Design and methods (3rd ed.). London: Sage Publications

Zapata, M. J., \& Hall, C. M. (2012). Public-private collaboration in the tourism sector: Balancing legitimacy and effectiveness in local tourism partnerships. The Spanish case. Journal of Policy Research in Tourism, Leisure \& Events, 4(1), 61-83.

Zott, C., \& Amit, R. (2007). Business model design and the performance of entrepreneurial firms. Organization Science, 18, 181-199.

Zott, C., \& Amit, R. (2008). The fit between Pproduct market strategy and business model: Implications for firm performance. StrategManag JStrategic Management Journal, 29, 1-26.

Zott, C., \& Amit, R. (2009). Business model design: An activity system perspective. Long Range Planning, 43(2-3), 216-226. https://doi.org/10.1016/j.Irp.2009.07.004.

Zott, C., Amit, R., \& Massa, L. (2011). The business model: Recent developments and future research. Journal of Management, 37(4), 1019-1042.

\section{Submit your manuscript to a SpringerOpen ${ }^{\circ}$ journal and benefit from:}

- Convenient online submission

- Rigorous peer review

- Open access: articles freely available online

- High visibility within the field

- Retaining the copyright to your article

Submit your next manuscript at $\boldsymbol{\sim}$ springeropen.com 